\title{
MEASURING THE COMPETENCE AND THE INDEPENDENCE OF AD HOC COMMITTEE AND ITS EFFECT ON THE PERFORMANCE OF GENERAL ELECTION
}

\author{
Ahmad Arif \\ Post-Graduate Student of Universitas Terbuka \\ Email Corresponding author:rasahmadarif@gmail.com
}

\begin{abstract}
The success of the election is very closely related to the way each election is held and carried out correctly. The human resource factor (SDM) is not only regarded as the determination of the success of election but also as the quality of the general election and democracy. The process of a general election in 2019 has been found that the ad hoc committee faced many obstacles, which were generally related to the voter data collection process, election socialization, voting and counting process, the recapitulation of the voting election, etc. To improve the quality of human resources in conducting the elections was necessary to be appropriately implemented in which it must be directed and planned. However, it became a significant barrier to a large number of ad hoc (temporary) committees. This research aimed to see the competence and independence of the ad hoc committee in the 2019 Simultaneous Elections in the City of Depok. This research used descriptive quantitative in which it was based on survey results, document reviews, and observations. The results showed that the competence and independence of the ad hoc committee effected significantly to support the success of the general election.
\end{abstract}

Keywords: Competence, Independence, Ad hoc Committee, General Election

\section{A. Background}

The general elections are complex political activities that do not merely depend on electoral procedures but also on political rights, community activities, political party functions, administration, the rule of law and justice, and so on. The quality of election committees is not easy to be measured because many factors are interrelated, changing, and growing. However, to assess the ability, integrity, and neutrality of elections can be based on statutory standards as an indicator. Most people, as well as the committees of the election, have a different understanding of good elections in terms that they are difficult to explain. "Luber Jurdil" or election which is direct, public, free, confidential, open, and fair," is a phrase commonly used to measure the quality of the committees. How the committees are able to understand and implement in carrying out each stage of the election is an exciting thing to be discussed and observed to improve the quality of election administrations.

In terms of the constitution, the election administration agency is an independent institution (independent); however, how to build and maintain independence (independence) both institutions and their general election committees are the main issues. The International Parliamentary Union and International IDEA has set the formulations and standards to be the measure in which it must be taken into consideration when forming and selecting the committees are: First, the institutional structure of the electoral committees must be determined based on national election laws that have exclusive authority and responsibility towards the institution lower. Second, the election administration agency at every level has authority and responsibility. Third, the composition of human resources with proper qualifications.

Based on the experience and observations of the election administration, the issues often occur and encountered by ad hoc committees are related to the preparation of the voter list, organizational management, voting, calculation, and recapitulation, and also the problems of the independence of election 
committees. The ad hoc committees also have to deal with potential problems such as disputes, disputes, and violations both in Bawaslu, DKPP, and in the Constitutional Court, and even the election crimes.

When it is classified, the violations of election crime cases consist of several types, namely money politics in the form of promising or giving something in the form of material / goods or money in which it can occur during campaign periods, quiet days or during elections, changing the results of election votes during voting or during the certificate results of vote counting, vote more than once or use the identity of other voters. Moreover, the implementation of the electoral stage is a related and tiered process, such as a cycle. The problems that occur at lower administrators will have an impact on administrators at the next level.

In the perspective and human resource management, especially in the elections and public administration, it becomes interesting about how the performance of the ad hoc committee carries out its duties in accordance with reasonably stringent principles and standards. This research attempts to see how much ad hoc committee performance is affected by competence and independence with restrictions on PPK and PPS in the 2019 elections.

\section{B. Literature Review}

\section{Competence}

\section{a. The Nature of Competence}

According to Spencer \&
Spencer which is quoted by

Moeheriono (2014) argues that competency is a characteristic that is the basis for those are related with the duties or essential characteristics of individuals who are related as cause and effect with criteria that are used as a reference, practical or superior performance at work or in certain situations. The ability to carry out the task based on skills and knowledge and supported by work attitudes which are demanded by work mentioned as competence. Competence is characterized by professionalism in a

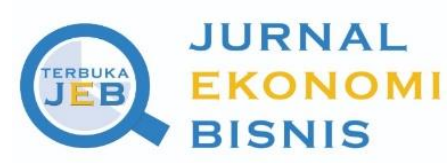

particular field shown by skills or knowledge as something important that is superior in that field. (Wibowo, 2017: 271).

The development of the individual's competence in terms of abilities and knowledge can be done through training and education activities. However, an individual's personality competence can also be known during the selection process. Inequality of competence of each individual enables us to distinguish someone with appropriate behavior and support the achievement of general average behavior. To achieve average or enough performance, it requires threshold competencies or essential competencies. The threshold competencies and essential competencies for a particular employee constitute a pattern or guideline in the selection of members (personnel selection), planning of task assignments (succession planning), performance appraisal, and career development. Spencer also argues that the components of individual competencies, namely: intellectual competence, emotional competence, social competence, and organizational competence.

\section{b. Competence Indicator}

The main component, which is an indicator of competence as stated by Hutapea and Thoha (2008) and also the State Personnel Agency (BKN) (2013) in decision number 46A, states that competence consists of knowledge, skills and behavioral attitudes. The three main components of competency formation can be explained as follows: (1) Knowledge, Knowledge plays a vital role in supporting the success of employees in carrying out the duties and responsibilities which are assigned to them. The knowledge and information are in accordance with the field they are 
in, for example, knowledge of computer languages, etc. With enough knowledge will be able to improve organizational efficiency.

(2) Skill (Skill), Skills have a role in carrying out the duties and responsibilities properly and optimally, for example, a computer programmer. Aside from employee knowledge and abilities, the most important thing becomes consideration is employee behavior.

(3) Attitude, A person's behavior patterns in carrying out their duties and responsibilities are in accordance with company regulations. If employees have the nature of supporting the achievement of the organization, then all tasks automatically assigned to it will be carried out as well as possible. Knowledge, skill and attitude competencies tend to be more visible (visible) and relatively on the surface (ends) as a characteristic possessed by humans.

\section{c. The Election Committees Competencies}

The indicators of the implementation of elections and integrity are the election committees' agency must be democratic. The election management agency is able to maintain its neutrality by not giving the legitimacy of the election process, so then the results of the election can be accepted by all parties. Besides, the responsibility for the electoral process which consists of several stages, the election committee is also responsible for political education for voters. Therefore, to improve the performance of the election committee, the necessary aspects are:

a) Maintaining Integrity;

b) Building People's Participation;

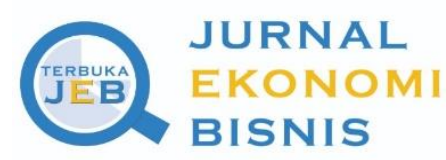

c) Having a clear rule of law (lawfulness);

d) Impartial and fair (Impartiality and fairness);

e) Ensuring Professionalism;

f) Maintaining the Independent;

g) Transparent;

h) On-time;

i) There is no violence (nonviolence);

j) Regularity;

k) Acceptance.

Competence describes the ability to conduct and manage the program, schedule, and stages of the election in a proper and measurable manner.

\section{Independence}

\section{a. The Nature of Independence}

In the Indonesian Dictionary (KBBI: 2008) stated that the word "Independent" is the existence of independence, independence, freedom, autonomy, in which it is not influenced or dominated personally or institutionally, or dependent on others. The word independent is often used in the fields of financial management, profession, economics, politics, and so on. Independent is the nature and attitude of the soul that is free and independent, not dependent on outside parties in meeting their needs. Freedom and independent soul is not meant that the committee does not need another party, but a character that always strives to face and solve its own problems. Independent can also be interpreted as an attitude of impartiality to all parties, has his own power, independent, not controlled by other parties. In addition, independence can be interpreted as an impartial perspective in carrying out functions and tasks. The independent mental attitude must include of Independence in fact and independence in appearance (Siti, 2017). 
The election committee must be neutral and impartial, and it can also be interpreted that an organizer or as an institution is not under the control of political parties or state officials who have an interest in the election process and results. Independence is not only interpreted as "independent, free, impartial, or impartial" to any person, organization or interest group, or can be interpreted as not influenced or dependent, independence can also be interpreted as strength, ethics, paradigm, and spirit which can be a guarantee that the process and results of the election implementation reflect the interests of a people, nation and state.

\section{b. The Independence of the general election agency}

In PKPU 36 of 2018, the independence of the general election agency covers three matters, namely:

(1) Institutional or structural independence. This independence shows that the institution of the general election is not part or subordinate to other state institutions or any institution of existing state institutions.

(2) Functional independence. This independence is intended to carry out the general election, and the election committee cannot be interfered with, ordered, or pressured by other parties.

(3) Personal independence. Being an impartial, honest, and fair (objective) election committee, having the capacity and capability, showing the personal independence of the election committee.

Political dynamics will significantly influence the election as an election competition where political actors involved as election participants (parties and candidates), supporters, bureaucracy, and voters

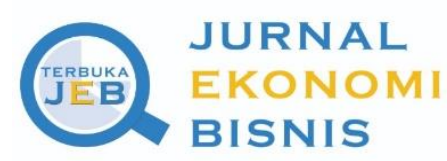

try to influence each other, including efforts to influence election administrators. The modus operandi of election code violations based on DKPP decision data shows the involvement of organizers, election participants, bureaucracy, and limited voters.

\section{The Performance of the Ad Hoc Committee}

a. The Nature of Performance

Mangkunegara (2016) stated that performance comes from the word job performance or actual performance (work performance or actual achievement achieved by someone). The meaning of performance is related to the work of the quality and quantity achieved by an employee in carrying out their duties in accordance with the responsibility given to him. Performance is the result of a process in which it refers, and it can be measured over a certain period of time under predetermined provisions or agreements (Edison, 2016). In general, performance can be interpreted as the whole work process of individuals whose results can be used as a basis for determining whether the individual's work is good or vice versa (Roziqin, 2017). Ilyas (2016) argues that performance is related to the appearance of the work of personnel both in quantity and quality in an organization. Performance can be the appearance of individual or working group personnel. The appearance of the work is not limited to personnel who hold functional or structural positions but also the entire range of personnel in the organization.

In reference to the above opinions of the experts, performance can be regarded as an achievement of results by individuals according to the role or task in an organization that is associated with a measure of values or 
standards of achievement of the organization.

\section{b. Factors that affect performance}

Based on Mangkunegara's explanation (2016) about factors that can affect performance are:

1) Ability. Psychological ability factors of individuals must meet the potential qualifications (IQ), and the average is (IQ 110-120) with an adequate education.

2) Motivation. Motivation deals with the form of an employee's attitude to face particular situations. Motivation is a condition that becomes a motivating factor for employees in the direction of organizational goals (work goals).

3) Attitude. Attitude is a mental picture that drives an employee to try to achieve maximum work performance. Factors the attitude of an employee who is ready both psychologically and physically (mental, physical, goal, and situation) will quickly understand the main goals and work targets to be achieved. The individual is able to utilize and create work situations. (Mangkunegara, 2016).

\section{c. The Nature of the Ad Hoc Committee}

Ad hoc committee is a term that is often used in organizational and research activities; it is derived from Latin which means "formed or intended for one merely purpose" or something "improvised." Then, this term is used in the committee / organization that aims to run or implement a particular program and is formed for a certain period of time.

1) The General Election Committee (KPU)

The general election committee is the national institution and it is an independent institution to carry out the elections. The existence of the $\mathrm{KPU}$ is tiered hierarchically from

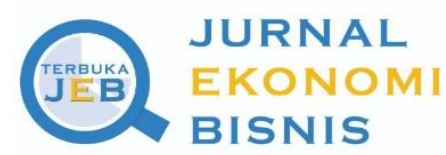

the central, provincial and district / city levels. KPU membership at the central, provincial, and regency / city is amount 5 to 7 people with a term of service for 5 years, while the existence of KPU, Provincial KPU and Regency / City KPU institutions at each national level is permanent.

2) Ad Hoc Committee

The election organizers in the administrative levels cover the districts, villages and polling stations (TPS), namely:

a) District Election Committee (PPK). Regency / City KPU forms PPK to carry out general Elections at the sub-district level. There are 5 PPK members and in carrying out their duties, they are assisted by secretarial staff. In conducting the general elections, PPK has the duties and authorities, namely:

- Collecting the results of voting from all polling stations, recapitulating the results of voting from all PPS in the working area, making minutes and certifying the results of the voting

- Assisting the KPU's tasks in carrying out elections.

b) Voting Committee (PPS).

Regency / City KPU forms a PPS to carry out elections in the urban village. PPS consists of 3 people who are appointed from independent community leaders based on the submission of officials at the village / urban village level. PPS in the administration of elections has duties and authorities, namely:

- Registering the voters;

- Appointing the registrars and registrars; 
- Submitting the voter lists to PPK;

- Recapitulating the results of voting from all polling stations in their working area and prepare minutes and certificates for recapitulation of voting results;

- Assisting the task of PPK.

c) Voters Organizing Group (KPPS), is a committee group formed by the PPS to carry out the voting at the polling station. The number of KPPS Members consists of 7 people.

\section{d. Ad Hoc Committee Performance Assessment Indicators}

To be able to assess performance appropriately, the measurement of observations is given to the indicators used. Ad Hoc Committee Performance Assessment Indicators, in this case, PPS is an evaluation in carrying out the duties and authority which is conducted for several months with the following criteria:

1) The ability to arrange voter lists on time and following the provisions;

2) The ability to appoint voters registrar and registrar (PPDP), and KPPS officers following regulatory criteria;

3) The ability to perform recapitulation of vote counting results from all polling stations in their working area and prepare minutes and certificate of recapitulation of vote counting results;

4) The ability to help KDP's tasks. Performance measurement of an organization can be sourced from reports and results of performance monitoring individually, or collectively, or a combination of both.

\section{Findings and Discussions}

\section{The Results of Partial Regression Analysis (t-Test)}

To find out individually on the effect of one independent variable on the dependent variable can use Partial Regression Analysis (t-test). If the significance value generated by the t-test is significant $<0.05$, it can be concluded that partially the independent variable has a significant effect on the dependent variable. The test results can be seen that the influence of Competence (x1) and Independent (x2) partially has a significant effect on performance. The SPSS calculation results obtained partial value of $\mathrm{t}$ as follows:

\section{Table 1. Partial Hypothesis Testing}

\begin{tabular}{|c|c|c|c|l|}
\hline $\begin{array}{c}\text { Variable } \\
\text { Independ } \\
\text { ent }\end{array}$ & $\begin{array}{c}\text { Coeffici } \\
\text { ent } \\
\text { Pathwa } \\
\mathbf{y}\end{array}$ & $\begin{array}{c}\boldsymbol{T} \\
\text { Val } \\
\text { ue }\end{array}$ & $\begin{array}{c}\boldsymbol{T} \\
\text { Tabl } \\
\mathbf{e}\end{array}$ & $\begin{array}{l}\text { Conclusio } \\
\mathbf{n}\end{array}$ \\
\hline $\begin{array}{c}\text { Competen } \\
\text { cy }\left(\mathrm{X}^{1}\right)\end{array}$ & 0.001 & 3.53 & 1,67 & $\begin{array}{l}\text { Competen } \\
\text { ce (X1) } \\
\text { partially } \\
\text { affects } \\
\text { performan } \\
\text { ce, which } \\
\text { is the first } \\
\text { hypothesis } \\
\text { (H1) to be } \\
\text { accepted }\end{array}$ \\
\hline Indepeden & 0.000 & 4.28 & 1,67 & $\begin{array}{l}\text { Independe } \\
\text { nce (X2) } \\
\text { partially } \\
\text { affects } \\
\text { performan } \\
\text { ce, which } \\
\text { is the } \\
\text { is the } \\
\text { second } \\
\text { hypothesis } \\
\text { (H2) be } \\
\text { accepted }\end{array}$ \\
\hline
\end{tabular}

The further explanation of the results above regarding the effect between variables:

a. The effect of Competence on Performance.

Based on the table shows that the Competency variable (X1) has a significant value of $0.001<0.05$. This indicates that $\mathrm{H} 1$ was accepted, and $\mathrm{Ho}$ was rejected because the significant value was less than $0.05(0.05)$. So it can be concluded that Competency 
(X1) partially influences performance; it means the first hypothesis (H1) is accepted.

b. The effect of the Independent on Performance.

Based on the table shows that the Independent variable (X2) has a significant value of $0,000>0.05$. This indicates that $\mathrm{H} 2$ is accepted, and $\mathrm{Ho}$ is rejected because the significant value is less than 0.05 (> 0.05). Thus, it can be concluded that Independence (X2) partially influences performance; it means the second hypothesis (H2) is accepted.

\section{The Results of Multiple Regression Analysis (Test F)}

To find out whether or not there is significant influence in the F test, there are two ways that can be used: First, we can compare F value with the F table. Second, we can also compare the significance value or probability value and SPSS calculation results whether the significance value is higher or smaller than the standard statistical value which is 0.05 .

\section{Table 2. Simultaneous Hypothesis Testing}

\begin{tabular}{|c|c|c|c|c|}
\hline $\begin{array}{c}\text { Variable } \\
\text { Independ } \\
\text { ent }\end{array}$ & $\begin{array}{l}\text { Coeffici } \\
\text { ent } \\
\text { Pathway }\end{array}$ & $\begin{array}{c}F \\
\text { Valu } \\
\text { e }\end{array}$ & $\begin{array}{c}F \\
\text { Tabl } \\
\text { e }\end{array}$ & $\begin{array}{c}\text { Conclusio } \\
\mathbf{n}\end{array}$ \\
\hline $\begin{array}{l}\text { Competen } \\
\text { cy }\left(\mathrm{X}^{1}\right)\end{array}$ & 0.000 & \multirow{2}{*}{$\begin{array}{c}45.92 \\
8\end{array}$} & \multirow[b]{2}{*}{3.18} & $\begin{array}{l}\text { Competen } \\
\text { cy (X1) } \\
\text { partial } \\
\text { effect on } \\
\text { performan } \\
\text { ce is the } \\
\text { first } \\
\text { hypothesis } \\
\text { (H1), to be } \\
\text { accepted }\end{array}$ \\
\hline $\begin{array}{l}\text { Indepeden } \\
\text { cy }\left(\mathrm{X}^{2}\right)\end{array}$ & 0.000 & & & $\begin{array}{l}\text { Independe } \\
\text { nce (X2) } \\
\text { partially } \\
\text { influential } \\
\text { on the } \\
\text { performan } \\
\text { ce that is } \\
\text { the second } \\
\text { hypothesis } \\
\text { (H2) to be } \\
\text { accepted }\end{array}$ \\
\hline
\end{tabular}

The data above shows that $\mathrm{k}=2$ (Xl and $\mathrm{X} 2$ ), and $\mathrm{n}=55$. Furthermore, this value is entered into the formula, then produces the number $(2 ; 55-2)=(2 ; 53)$, then we make this number as a reference to find out the value of the $F$ table in the distribution of the statistical table $\mathrm{F}$ value is 3.18. Further, it is known that the $F$ table value is 3.18. Because the $F$ value of 45.923 is higher and the F value of the table is 3.18 , it can be concluded that the independent variables $\mathrm{Xl}$ and $\mathrm{X} 2$ (simultaneously) effect on the dependent variable (Y). R Square of this research is 0.639 . It means that $63.9 \%$ of the Competency and Independent variables can explain the Performance variable (Y). Meanwhile, the rest $(100 \%$ $63.9 \%=36.1 \%)$ is explained by other variables that are not used in this research.

\section{. Conclusion}

The hypothesis that the performance of the Ad Hoc Committee for organizing elections is influenced by competence is illustrated in this study. Nevertheless, there is still a gap between the knowledge and understanding of the ad hoc committee and the technical procedures for conducting elections in the KPU Laws and Regulations. For this reason, it is important to increase the knowledge and understanding of electoral ad hoc committees by providing literacy materials to facilitate understanding of the KPU Laws and Regulations in the form of member pocketbooks or organizer handbooks.

The performance of the Ad Hoc Committee was also influenced by the attitude as an independent election organizer. In this study, impartial and objective indicators are still in the sufficient category, this is vulnerable to weakening efforts so that strengthening and role models from the organizers are needed, especially at the level of permanent organizers (KPU). Besides, simultaneous training programs or materials and information need to be made using affordable audio/video technology and communication devices. This strengthening is to better understand changes or renewal of election procedures and other regulatory provisions such as about ethics and criminal election. 


\section{REFERENCES}

Bangun, Wilson. (2012). Manajemen Sumber Daya Manusia. Jakarta: Erlangga

Catt, Helena et al., eds. (2014). Electoral Management Design: Revised Edition. Revised Ed. International IDEA. Stockholm.

Peraturan Menteri Pendidikan dan Kebudayaan Nomor 54 tahun 2013 tentang Standar Kompetensi Lulusan Pendidikan Dasar dan Menengah. http://www.bsnp-indonesia.org, September 2019).

IDEA, International. (2002). Standar-Standar Internasional Untuk Pemilihan Umum: Pedoman Peninjauan Kembali Kerangka Hukum Pemilu. International IDEA. Stockholm.

IDEA, International. (2016). Electoral Management Design: The International IDEA Handbook. International IDEA. Stockholm.

Indriantoro, Nur dan Bambang Supomo. (2011). Metodologi Penelitian Bisnis Untuk Akuntansi Dan Manajemen. BPFE. Yogyakarta.

Moeheriono. (2014). Pengukuran Kinerja Berbasis Kompetensi, Edisi Revisi, Jakarta: Rajawali.

Nazir, Moch. (2011). Metode Penelitian. Bogor: Ghalia Indonesia.

Rivai, Veithzal, (2009). Manajemen Sumber Daya Manusia Untuk Perusahaan dari Teori ke Praktek. Jakarta: Raja Grafindo Persada.

Sedarmayanti. (2016). Manajemen Sumber Daya Manusia, Reformasi Birokrasi, dan Manajemen Pegawai Negeri Sipil. Edisi Revisi. Bandung: PT. Refika Aditama.

Setiawan, Ferry dan Dewi, Kartika. (2014). Pengaruh Kompensasi Dan Lingkungan Kerja Terhadap Kinerja Karyawan pada CV. Berkat Anugrah. Jurnal. Denpasar: Universitas Udayana.
Sudarmanto. (2015). Kinerja dan Pengembangan Kompetensi SDM. edisi tiga. Yogyakarta: Pustaka Pelajar.

Sudarmanto. (2015). Kinerja dan Pengembangan Kompetensi SDM. edisi tiga. Yogyakarta: Pustaka Pelajar.

Sugiyono. (2016). Metode Penelitian Kuantitatif, Kualitatif, dan $R \& D$. Bandung: Alfabeta.

Sutrisno, Edy. (2010). Manajemen Sumber Daya Manusia. Edisi Pertama, Cetakan ke-2. Jakarta: Kencana.

Wibowo, (2016). Manajemen Kinerja. Edisi Kelima. PT. Rajagrafindo Persada Jakarta-14240. 